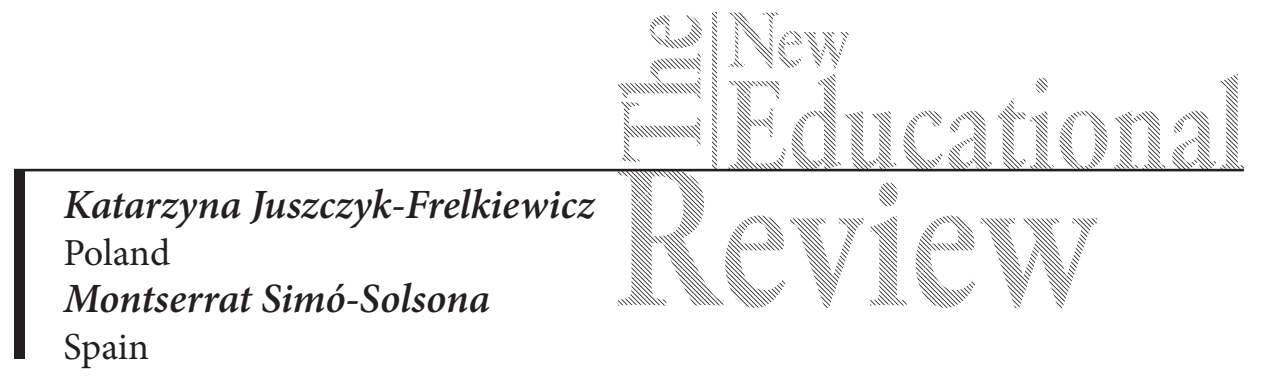

\title{
The Shape of the Contemporary Family in Poland and Spain
}

DOI: 10.15804/tner.2015.41.3.20

\begin{abstract}
This article presents the shape of the contemporary family in Poland and Spain which is based on developments that have taken place in these countries in relation to family formation and dissolution through an analysis of indicators such as: marriage, divorce, fertility, births outside marriage during the last three decades. The shape of the contemporary family keeps changing in both these countries, but the speed of changes is different. In Poland, changes in family formation have occurred much more slowly than in Spain, where the family is not only heterosexual marriage, but also homosexual marriage.
\end{abstract}

Keywords: family, marriage, divorce, birth outside marriage, fertility, cohabitation

\section{Introduction}

Not more than 40 years ago, marriage used to mark the start of a first union for most couples in Europe, the overwhelming majority of children were born and reared in marital unions, and a spouse's death (rather than dissolution) was the far most common reason for the termination of the union (Festy, 1980, pp. $311-315$, as cited in: Nazio, 2008, p. 1). Since the late 1960s and early 1970s, however, family living has undergone profound transformations with marriage postponement, rise in cohabitation (particularly since the beginning of the 1980s), lowering and delayed fertility, and increasing divorce rates (Kiernan, 2000, p. 1, as citied in: Nazio, 2008, p. 1), which have impacted on the prevalence and meaning 
of marriage (Axin, Thornton, 2000, pp. 147-169, as cited in: Nazio, 2008, p. 1). Nowadays, in many European countries cohabitation has increasingly become a common way of starting a first union. Together with cohabitation, non-marital childbearing has increased to unprecedented levels (Kiernan, 2001, pp. 1-21 as cited in: Nazio, 2008, p. 1), while lifelong marriage has been progressively postponed and eroded by divorce.

Legal alternatives to marriage, like registered heterosexual and homosexual partnership (cohabitation union), have become more widespread and national legislation has changed in many European countries (e.g. Spain, France, Sweden, Norway, the Netherlands) to confer more rights on unmarried couples. In Poland there is no possibility to register a heterosexual or homosexual partnership, whereas in Spain it is possible to register not only a homosexual partnership, but also marriage. Both countries, Poland and Spain, are mostly Roman Catholic, but in Spain changes in the family unit are occurring faster than in Poland, where society is more conservative.

All these changes have significant consequences for the demographic structure of the population as well as for private life, such as one's own beliefs and values, and public domains of people's lives, e.g., aspects related to the integration of women into the labour market and who takes care of children.

\section{The main demographic indicators of family life in Poland and Spain - methodological assumptions}

Poland and Spain follow different evolution concerning family structure. Historical facts, political system and the predominant social value system are some of the main factors influencing the understanding of the distinct development of family concept in both countries.

Spanish family continues being an important issue for Spanish society (Alberdi and Escario, 2003, p. 15), but its conception and its main function have changed throughout the last decades. The traditional family is transformed into modern family, changing its meaning from a survival institution to a social institution with individual freedom. The traditional family was characterized by a pronounced hierarchic line, where women were completely dependent. Its main function was to guarantee reproduction and protection of their members (Alberdi, 1995, p. 2). The hegemonic influence of the Roman Catholic Church supports the delay of this modernization process (Flaquer, 2000), specially represented by the Roman Catholic organization Opus Dei (Fernández-Mostaza, 2000). The contemporary 
family replaces need by freedom. The Spanish Constitution in 1978 was the trigger for these family transformations: equality of the sexes, equal rights for children independently of their civil situation or kind of relation between their parents. The same text of the Constitution contributes to this modernization in the sense the legislative text does not specify any clear definition of the concept of family unit. In consequence, it allows wide and diverse definitions: from the most traditional conception to the inclusion of excluded collectives such as homosexual couples and mono-parental families. One significant step towards the modernization of the family institution was taken in 1981, when divorce was approved and another one in 2005, when homosexual marriage was approved, with the same rights and responsibilities as heterosexual marriages. The progress has been notable and comparable to the most advanced countries in Europe due to legislative changes; however, a lot of work remains to be done in the private domain.

The Polish family has been changing more slowly than the Spanish family. There are no homosexual families (no possibility to register) and even the legislation acts do not respect cohabitation (heterosexual or homosexual), thus they do not have the same rights as traditional marriages. Yet, the number of cohabiting couples is increasing from year to year, making this phenomenon notable from the social point of view. Social opinion on this phenomenon is changing from traditional opinion (rather negative) to the more open, accepting, tolerant, liberal opinion.

This article is generally based on data from Eurostat (http://ec.europa.eu/ eurostat), which is the leading provider of high quality statistics on Europe. In order to compare the main demographic indicators of family life in Poland and Spain we have used data with indicators of marriages, divorces, fertility, births outside marriage, the number of cohabiting couples and the number of homosexual marriages (only in Spain) in the last three decades. This information shows the direction of changes in the research into social phenomena and the shape of the contemporary family in Poland and Spain.

\section{Marriages}

Recent demographic data shows that the number of marriages per 1000 persons has decreased in Poland and Spain during the last decades, while the number of divorces has increased. An increase in the proportion of children who are born into unmarried couples is also apparent (http://ec.europa.eu/eurostat/statistics-explained/index.php/Marriage_and_divorce_statistics). 


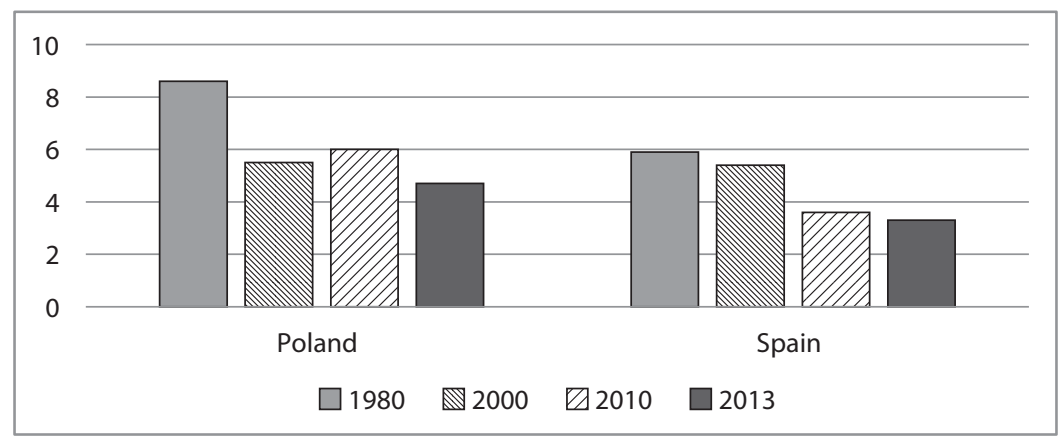

Graph 1. Marriage rates in Poland and Spain in 1980-2013

Source: Author's graph on data from Eurostat: http://ec.europa.eu/eurostat/ statistics-explained/index.php/File:Crude_marriage_rate,_selected_years,_1960 \%E2\%80\%932013_(per_1_000_inhabitants)_YB15.png - 27.07.2015.

As shown in Graph 1, there are differences between the number of marriages in Poland and Spain in the last three decades. Both of them constantly decrease, although Poland does not show a clear pattern. In 1980 the marriage rate in Poland (8.6) was much higher than in Spain (5.9). Twenty years later, in 2000, the indicators of marriages in both countries were very similar (Poland 5.5, Spain 5.4). In 2010, the marriage rate in Spain decreased to 3.6 while Poland it increased to 6.0. In 2013 a decrease in the number of marriages was observed - in Poland the indicator was 4.7 and in Spain 3.3. Not only are the marriage rates different while comparing both countries, but also the age of people entering their first marriage. From 2005 to 2013, the age at the first marriage showed an increasing tendency in both countries. Besides, men were getting married later than women in Spain and also in Poland. However, some differences can be seen: the Spanish were getting

Table 1. Mean age of men and women at first marriage in Poland and Spain, 2005-2013

\begin{tabular}{lcccccccc}
\hline & \multicolumn{2}{c}{2005} & \multicolumn{2}{c}{2010} & \multicolumn{2}{c}{2012} & \multicolumn{2}{c}{2013} \\
\cline { 2 - 9 } & Men & Women & Men & Women & Men & Women & Men & Women \\
\hline Poland & 27.7 & 25.3 & 28.4 & 26.1 & 28.7 & 26.3 & 29 & 26.6 \\
\hline Spain & 31.6 & 29.4 & 33.1 & 30.9 & 33.7 & 31.6 & 34.4 & 32.2 \\
\hline
\end{tabular}

Source: Eurostat. http://ec.europa.eu/eurostat/web/population-demography-migration-projections/ marriages-and-divorces-data/database. 

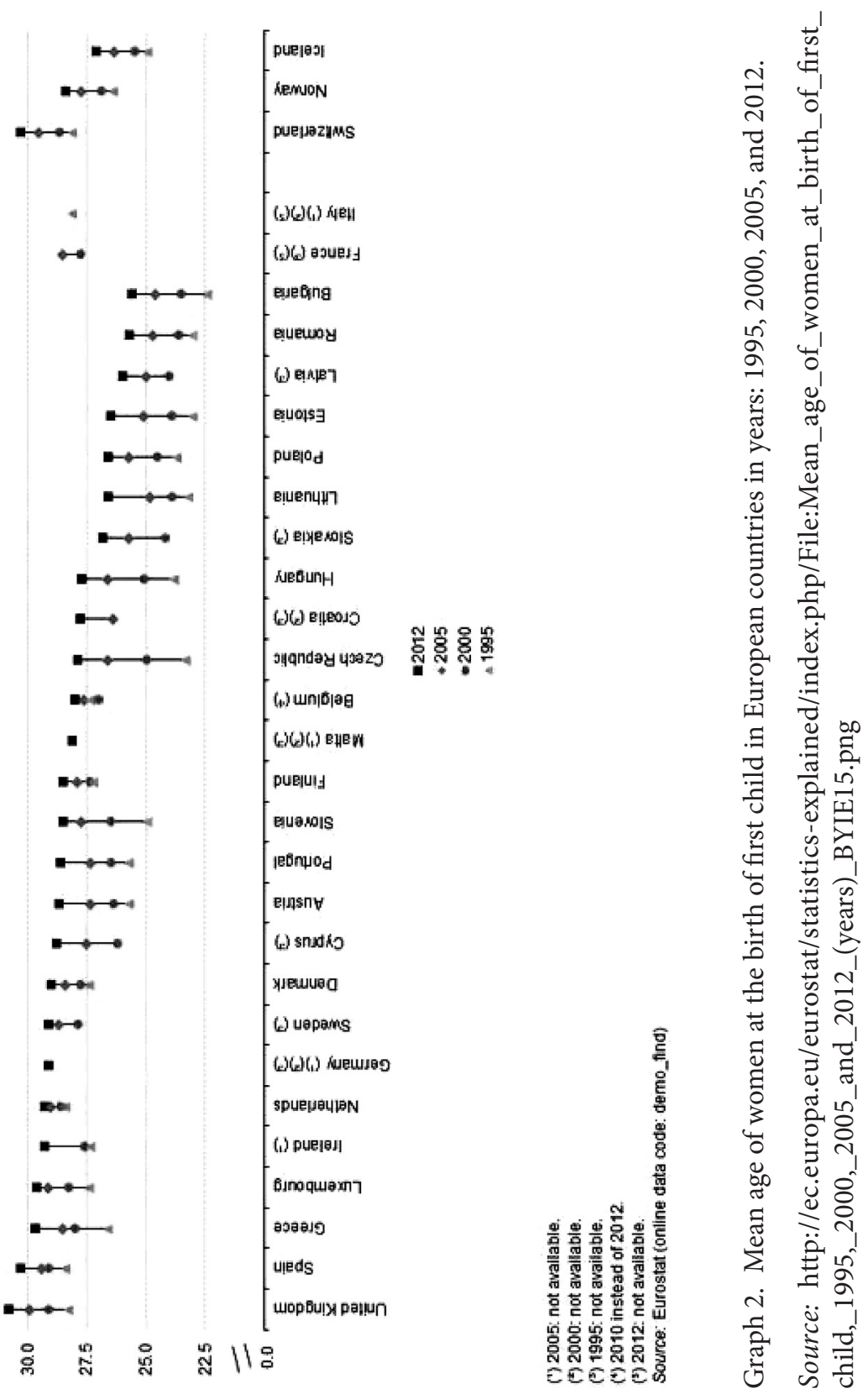

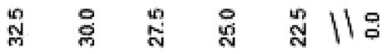


married later than the Polish, approximately by four years if we compare the same sex (cf. Table 1).

The mean age of women giving birth to their first child has increased in Poland and Spain and also across all EU Member States in the last three decades. This can be explained, in particular, by a higher proportion of women continuing their studies into higher education, a larger proportion of women entering and remaining in the workforce, as well as changes in traditional family units (fewer people getting married, getting married later, etc.) (Mills, Rindfuss, McDonald, 2011).

Graph 2 provides information on the mean age of women at first childbirth in European countries. Spain was one of the two countries where the mean age of women at childbirth was over 30 years in 2012 (30.3). The second country was the United Kingdom (30.8). In Poland this age was lower and oscillated around 26.5 years.

\section{Divorces}

The marriage breakdown has been and remained, along with falling birth rates, a more dramatic phenomenon in the recent evolution of the family (Alberdi, 1995, p. 26). In all OECD countries it is possible to divorce, but there is considerable cross-country variation in the length and nature of the divorce process, and this difference should be borne in mind when comparing divorce rates and mean durations of marriage across countries (http://www.oecd.org/els/family/ SF3_1_Marriage_and_divorce_rate_Jan2014.pdf ).

In Poland, in 1980, the divorce rate was 1.1 and in 2000 it was the same. In Spain, until 1981 divorce was not possible by law, that is why there is no data from 1980. In turn, in 2000 the indicator of divorce was 0.9, i.e. less than in Poland. In 2010 in Spain there were more than twice more divorces than in 2000, and in Poland a smaller increase, to 1.6, was observed (cf., Graph 3). In Poland the divorce rate has a tendency to slow down or remain at the same level, but in Spain there is a different pattern: legislation affects directly the divorce rate. From the 1980 s to 2000 there was an increase in it due to the possibility to get divorced; this expansion matches the economic boom from 2000 to 2010. After it, the economic recession made it more difficult to divorce as it implies more daily life expenses: two households, divorce costs and sometimes, child support. It would be interesting further explore the relation between these paired social facts: economic recession and divorce rate. 
According to the data from the Demographic Yearbook of Poland (2014, p. 285), most couples divorced in the early years of marriage, i.e., between 0 to 4 years, - in 2013 the number of divorced people was 15,739; between 5 to 9 years of marriage duration the number of the divorced was 14,133 and between 10 to 14 years there were 10,406 of the divorced. In Poland, the shorter the marriage is, the more couples get divorced. In Spain, the tendency is completely opposite. Divorce is a decision made later, when the couple has lived together for more than five years. In 2013, the average duration of marriage was 15.5 years (Instituto Nacional de Estadística (INE), 2014, http://www.ine.es/prensa/np867.pdf).

Specifically, $29.37 \%$ get divorced after more than 20 years of marriage and another substantial $23.21 \%$ get divorced after a period from 5 to 10 years of marriage (data on the divorce rate in Spain has improved in the recent years due the availability of judicial sources. Spanish Statistical Office (INE) states that some data from 2013 is not directly comparable with the previous years). Logically, the couples are supposed to be older. In 2013,24.35\% of the total divorce rate concerned spouses who were $40-49$ years old and, $10.02 \%$ of the spouses were $50-59$ years old. They are couples who get married after a long time of cohabitation, and then they get divorced.

Following this profile, one could suppose that they are families without children or children old enough. This hypothesis is partially confirmed: although $47.79 \%$ of the divorces in 2013 comprised couples with minor children, a noticeable $43.19 \%$

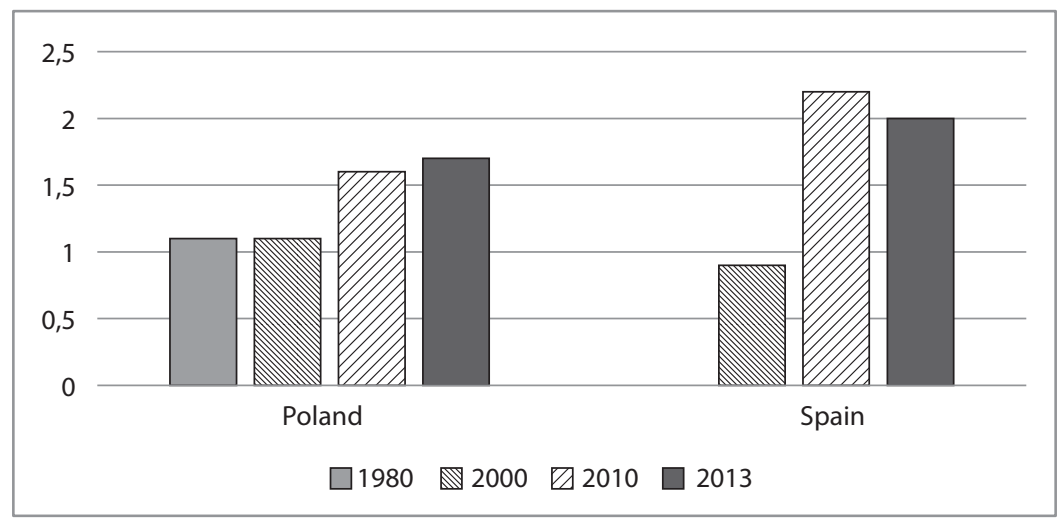

Graph 3. Divorce rates in Poland and Spain in 1980, 2000, 2010, and 2013.

Source: author's graph on data from Eurostat: http://ec.europa.eu/eurostat/statistics-explained/index.php/File:Crude_divorce_rate,_selected_years,_1960\%E2\%80\%932013_ (\%C2\%B9)_(per_1_000_inhabitants)_YB15.png - 27.07.2015. 
were couples with no children. The available data also shows that the more children there are in the family, the less likely it is for the spouses to get divorced.

Another hypothesis concerns the origin of the spouses getting divorced. Most of the divorced couples in 2013 were either Spanish or one spouse was Spanish and the other European. Divorce is not a common "decision" for non-European people. Divorce could become a threat to ensure social integration of migrant people; particularly women. It would be interesting to further research the effect of divorce on women, when they have to live alone, sometimes with dependent children and very often without a close-family network.

In 2013, the main causes of divorce in Poland (Demographic Yearbook of Poland 2014, p. 287) were the following:

- discrepancy of characters - 17,949 divorces;

- infidelity - 5,589 divorces, twice more on the part of the husband;

- alcohol abuse - 3,507 divorces, thirteen times more on the part of the husband;

- long absence - 1,332 divorces;

- financial misunderstanding - 1,110 divorces.

These statistics show that Polish people cannot compromise in marriage and often argue. Many people who have love affairs outside of marriage, very often decide to change the life partner. Some of them are addicted to alcohol. In Spain, there is no official data about the main causes of divorce.

\section{Fertility}

Fertility steadily declined from the mid-1960s to the turn of the century in the EU Member States. However, in later years the total fertility rate in the EU-28 showed some signs of rising again; however, this development stopped in 2010 and a decline has been observed again since 2011 (Eurostat - http://ec.europa. eu/eurostat/statistics-explained/index.php/Fertility_statistics). There are different explanations for this upturn and stagnation: economic recession, the entry-exit of women in the labor market and the cut of social policies. All of them could be some of the main causes to take into account.

In Spain (2.2) in 1980 and in Poland (2.06) in 1990 the fertility rates were at the generation replacement level. From year to year fertility rates were dropping in both countries. This means that from year to year fewer children were born. In Spain, in 1990 the fertility rate was 1.36 and in Poland in 2000 it was 1.37, which means that changes in fertility occurred faster in Spain than in Poland. In 2013 
fertility rates were at a similar level, under generation replacement (cf., Graph 4). A lower fertility rate has an influence on social policy, pension, labor market, education, etc.

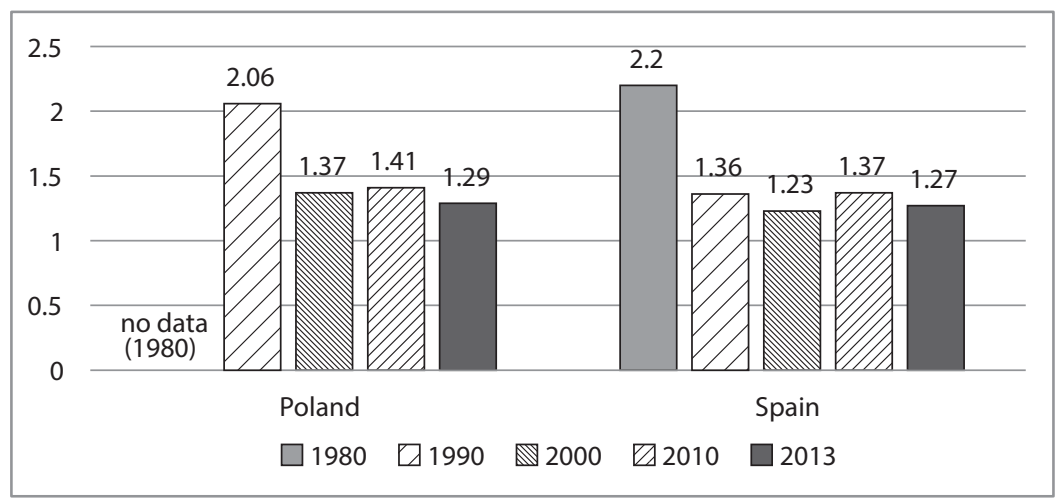

Graph 4. Fertility rate in Poland and Spain in 1980, 2000, 2010, and 2013.

Source: http://ec.europa.eu/eurostat/statistics-explained/index.php/File:Total_fertility _rate,_1960\%E2\%80\%932013_(live_births_per_woman)_YB15.png - 28.07.2015.

\section{Births outside marriage}

An important indication of changing attitudes toward family formation is the rapidly rising trend of births outside marriage. Back in 1960, births outside marriage were virtually unheard of and were often kept as secret as possible. Fifty years ago, people were expected to marry first and then start a family. Times have certainly changed. In many countries today, non-marital childbearing has become routine. The pressure seems to be off, as the younger generation lives differently from earlier generations. Now, however, births outside formal marriage occur to cohabiting couples who care for the child and maintain a household the same as their married counterparts. Nonetheless, it has been surprising to many that this new pattern of childbearing has also taken place in countries where social and religious norms would seem to be against it: Ireland, Italy, Portugal, and Spain are examples (Haub, 2013).

According to the data from Eurostat (http://ec.europa.eu/eurostat/statistics -explained/index.php/File:Live_births_outside_marriage,_selected_years,_1960\% E2\%80\%932013_(share_of_total_live_births,_\%25)_YB15.png ), since 1980 the 
number of births outside marriage has been rising in Poland and Spain, but this phenomenon is faster in Spain than in Poland. In Poland, in 1980, there were 4.8\% of births outside marriage - at the same level as in Spain (3.9\%). In 2000, in Poland there were $12.1 \%$ of births outside marriage, while in Spain there were $17.7 \%$. During the next ten years, the number of births outside marriage in Spain increased rapidly and in 2010 it was 35.5\% and in 2013 40.9\%. In Poland, in 2010, the rate was $20.6 \%$ and in 2013 23.4\% (cf., Graph 5).

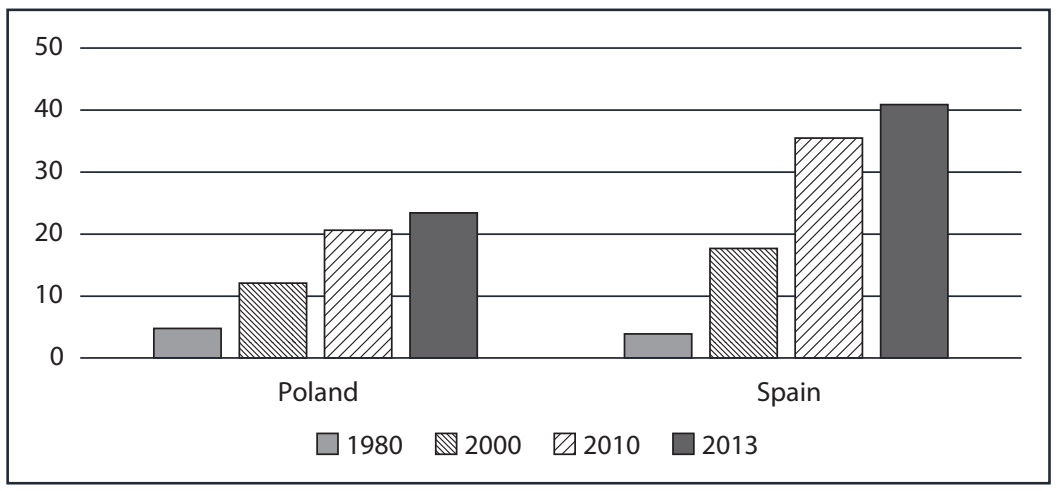

Graph 5. Births outside marriage in Poland and Spain in 1980, 2000, 2010, and 2013.

Source: http://ec.europa.eu/eurostat/statistics-explained/index.php/File:Live_births_outside_ marriage,_selected_years,_1960\%E2\%80\%932013_(share_of_total_live_births,_\%25)_YB15. png

These demographic data shows that in the future the number of births outside marriage will be higher because of the social acceptance for cohabiting couples and births outside marriage and lack of social pressure to get married.

\section{Cohabitation and same-sex partnerships}

In the process of the transformation of modern family a very important role is played by the phenomenon of cohabitation, other than described above demographic behaviors associated with the family.

Cohabitation involves changing the perceptions of the family, fulfilling its functions, relations of partnership and changes in the role division. An increasing number of couples resign or postpone marriage, leave this very important decision for later, preferring to live in cohabitation partnership, which implies many consequences and effects that are reflected in changes in social behavior and demo- 
graphics. These changes result in a decreasing number of people getting married, an increase in the age of getting married, increase in the divorce rate, lower fertility rate and an increase in births outside marriage (Juszczyk-Frelkiewicz, 2014, p. 10).

In Poland there is no possibility to register a cohabitation union (heterosexual or homosexual), nevertheless many people live in that kind of partnership and they treat cohabitation as an introduction to marriage (they consider it as engagement time and living together in the same household) or a life form alternative to marriage. In Poland, these unions are not treated as marriage because they do not have the same rights as marriage - it is a huge disadvantage. Moreover, in that country there is growing social acceptance and tolerance toward this phenomenon and from year to year more and more people decide to live in cohabitation relationships (Juszczyk-Frelkiewicz, 2014; Kwak, 2005; Slany, 2006).

According to the data from the National Censuses (Demographic Yearbook of Poland 2014, p. 205), in Poland, in 2002, there were nearly 200 thousand cohabiting couples. In 2011 (The report of the results: The National Census of Population and Housing 2011, 2012, pp. 56-57) there were about 390,000 couples who lived without marriage, i.e., about 780,000 people living in cohabitation relationships. More cohabiting partners live in cities (602.0) than in villages (178.5) (cf., Table 2). Statistics show that the number of cohabiting couples in Poland keeps rising and in the future there will be more cohabitants.

Table 2. Number of cohabiting partners in Poland in 2011

\begin{tabular}{lc}
\hline Specification & $\begin{array}{c}\text { Partners } \\
\text { (in thousands) }\end{array}$ \\
\hline Total & 780.5 \\
\hline women & 382.8 \\
\hline men & 397.8 \\
\hline city & 602.0 \\
\hline village & 178.5 \\
\hline $\begin{array}{l}\text { Source: Raport z wyników. Narodowy Spis Powszechny } \\
\text { Ludności i Mieszkań 2012, Główny Urząd Statystyczny, }\end{array}$ \\
\hline
\end{tabular}

Like in Poland, in Spain marriage is not the only socially accepted way of formalizing a relationship. During the last decades, Spain has made a big effort to establish legislation to regularize other forms apart from marriage. Comparison of the results of the Fertility Survey carried out in 1985 and a similar survey carried out in 1999 reveals huge changes: in 1985, the majority of women lived with 
a spouse (conjugal nucleus), with percentages oscillating from $76.14 \%$ to $87.23 \%$ depending on the age group. The lowest percentages were $9.69 \%$ of $18-19$-yearold women and $39.65 \%$ of 20-24-year-old women. Young women were supposed to live at home with their parents. The other forms were not common. In 1999 the situation changed completely. The older women are, the more of them are in the conjugal nucleus (marriage), but with lower percentages comparing to 1985 (from 21 to 23\%). On the contrary, younger women are mostly in other types of cohabitation, e.g., $27 \%$ of women from 25 to 29 years of age lived with a stable partner in the same home; a similar percentage of them lived with a stable partner, but in a different home (28.88\%) (cf., Table 3). Cohabitation without marriage is increasingly accepted by the Spanish public opinion. Different surveys carried out in the last decades show social acceptance of cohabitation as a stage prior to marriage or an alternative of it (cf., Alberdi and Escario, 2003).

Table 3. Women and cohabitation types in Spain (1999) (in percentages).

\begin{tabular}{lcccccc}
\hline & $\begin{array}{c}\text { With } \\
\text { a spouse }\end{array}$ & $\begin{array}{c}\text { With a stable } \\
\text { partner at } \\
\text { home }\end{array}$ & $\begin{array}{c}\text { With a stable } \\
\text { partner } \\
\text { outside home }\end{array}$ & $\begin{array}{c}\text { In occasional } \\
\text { relationships }\end{array}$ & $\begin{array}{c}\text { Other } \\
\text { situations }\end{array}$ & Total \\
\hline $\begin{array}{l}15-19 \\
\text { years old }\end{array}$ & 0.21 & 5.87 & 16.88 & 28.90 & 35.93 & 1324269 \\
\hline $\begin{array}{l}20-24 \\
\text { years old }\end{array}$ & 1.58 & 11.05 & 44.70 & 31.39 & 24.47 & 1591015 \\
\hline $\begin{array}{l}25-29 \\
\text { years old }\end{array}$ & 11.04 & 27.00 & 28.88 & 21.20 & 14.95 & 1612647 \\
\hline $\begin{array}{l}30-34 \\
\text { years old }\end{array}$ & 22.16 & 23.38 & 6.19 & 6.39 & 8.11 & 1582180 \\
\hline $\begin{array}{l}35-39 \\
\text { years old }\end{array}$ & 23.71 & 17.40 & 1.72 & 5.25 & 5.35 & 1494625 \\
\hline $\begin{array}{l}40-44 \\
\text { years old }\end{array}$ & 21.62 & 7.09 & 1.15 & 5.03 & 5.70 & 1343937 \\
\hline $\begin{array}{l}45-49 \\
\text { years old }\end{array}$ & 19.68 & 8.21 & 0.48 & 1.83 & 5.49 & 1216564 \\
\hline \begin{tabular}{l} 
Total \\
\hline
\end{tabular} & 100.00 & 100.00 & 100.00 & 100.00 & 100.00 & 10165237 \\
\hline
\end{tabular}

Source: Fertility Survey 1999 (Spanish Statistical Office (INE).

One of the most decisive contributions to the transformation of Spain, making it comparable to other developed countries in Europe, was the legalization of homosexual marriage in July 2005. Under the left-wing government, with a strong opposition by the Catholic Church and other conservative organizations, 
the Spanish Civil Code was modified in order to award rights to these couples in terms of adoption, inheritance and pension.

Marriages between people of the same sex represented only $1.96 \%$ of the total marriages in 2013. The number of homosexual marriages in Spain keeps stable after a rise in the first years. Marriages between men are always higher than marriages between women, especially from 2006 to 2011, although they seem to be similar during 2012 and 2013 (cf., Graph 6).

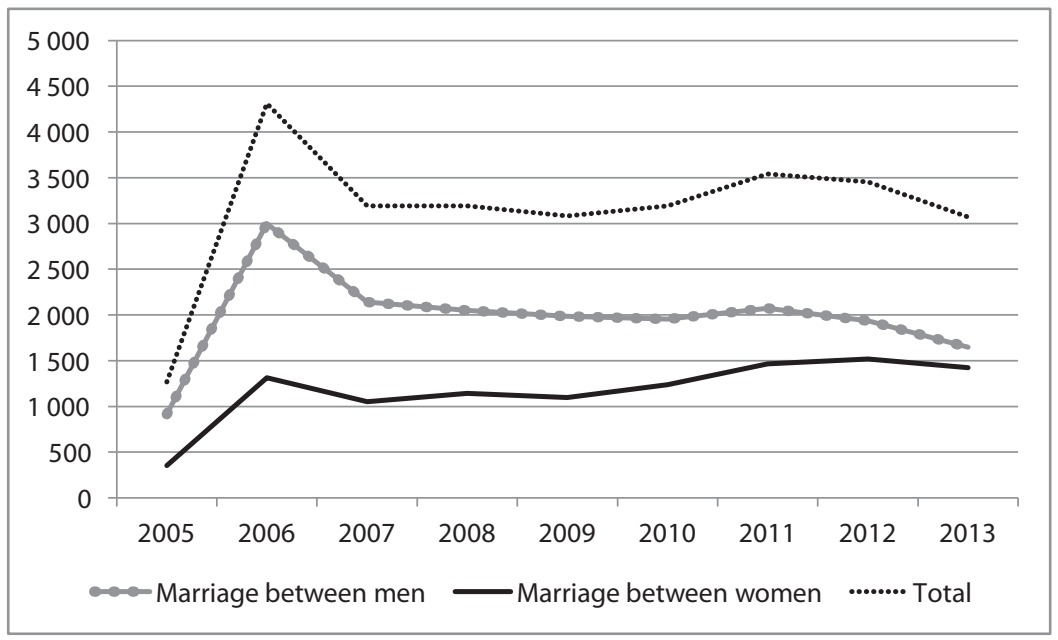

Graph 6. Number of homosexual marriages in Spain, 2005-2013.

1 As the law was passed on the 3rd of July 2005, the number of homosexual marriages refers to only five months.

Source: Spanish Statistical Office (INE).

Graph 7 shows the number of homosexual marriages by the age of each member of the couple. There is an analogous trend in both types of homosexual marriages; they are mainly from 25 to 39 years old. But in the case of marriages between men, another significant age group is those who are from 40 to 54 years of age. This age group is not so relevant in the case of marriages between women.

To close this section, we analyze two more socio-demographic characteristics of homosexual marriages: education level and occupation. The traditional profile of homosexual people is young, with high education level and high skilled occupation that allow them a high quality of life. As far as education level is concerned, it is slightly higher in marriages between men than in marriages between women. $17.48 \%$ of the members of the marriages between men in 2013 (1648) had a uni- 


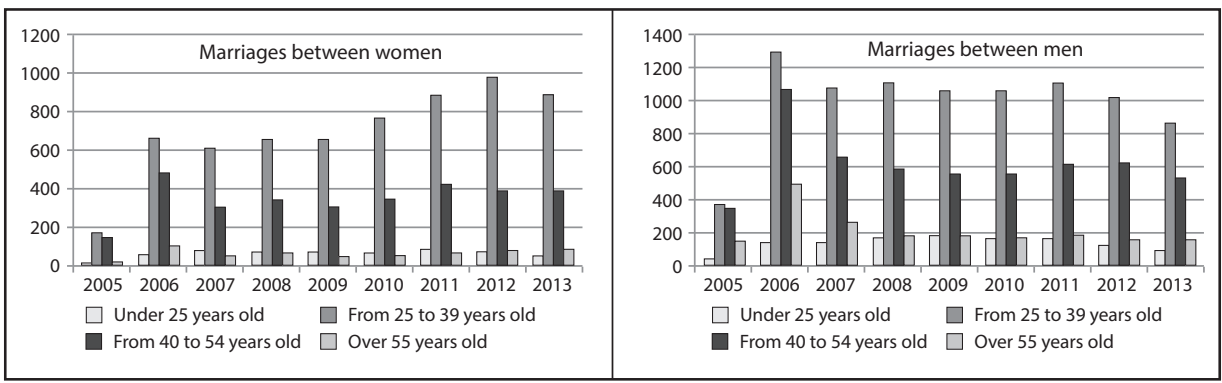

Graph 7. Homosexual marriages by age of spouses in Spain, 2005-2013. Source: Spanish Statistical Office (INE).

versity degree; $15.29 \%$ of them had secondary education. In the case of marriages between women, in 2013, 21.57\% of the members (1423) had a university degree; $14.20 \%$ of them had secondary education, and $8.71 \%$ had primary education. According to the analyzed data, homosexual marriages are more common between people with similar levels of education.

Together with the education level, we examined what kind of occupations homosexual marriages had. In the case of marriages between men, in 2013 most of them were people working in the same job, e.g., catering, personal, security and sales services (9.04\%) and technical and scientific professionals (6.07\%). In the case of marriages between women, the situation was similar; most of them were technical and scientific professionals (10.26\%); 6.61\% were marriages in which both spouses worked in catering, personal, security and sales services and $4.99 \%$ were administration officers. Following the same trend in the education level, homosexual marriages were mostly people doing the same, usually, medium- and high-qualified jobs.

\section{Conclusions}

Analysing the demographic basic indicators allows for the conclusion that Poland and Spain have a different conception of the contemporary family. Although the trend seems to be same, the speed of this modernization is different. In Poland changes are slower than in Spain. New types of living together are appearing and they are being socially accepted by Spanish society and slightly less by Polish society. Changes in legislation have helped in social assimilation. These 
affect not only the main sense of the family, but also the social composition of households.

Further information is needed to continue exploring the consequences for the social structure, and especially the values related to the main function of the family as a social institution. New issues should be taken into account such as how the role of women is affected by this family evolution, how the contemporary family ensures equal rights of men and women, and what role secularization will play in Polish and Spanish society in order to accept more different types of living together. One of the key questions is which pattern young generations will follow. Polish and Spanish youth understand and "use" the family institution according to their own needs. Young generations in Poland and Spain will have to face the main dilemmas of their individual freedom and establish their commitment to the family; they should choose between solidarity and rational estimation, autonomy or security, innovation or stability, among others. Both these generations live in democratic periods and are influenced by the same contemporary events. In this way, both countries are expected to have similar patterns and the same speed of changes of the evolution of the family.

\section{References}

Alberdi, I. (dir) (1995), Informe sobre la situación de la familia en España, Ministerio de Asuntos Sociales, Madrid.

Alberdi, I., Escario, P. (2003), Flexibilidad, Eleccción y Estilos de Vida Familiar. Ministerio de Trabajo y Asuntos Sociales, Madrid.

Axinn W.G., Thornton A. (2000), The transformation of the meaning of marriage. In Waite L. et al. (Eds.), Ties that bind. Perspectives on Marriage and Cohabitation, New York, pp. 147-169.

Demographic Yearbook of Poland, GUS, Warszawa 2014, p. 205.

Fernández-Mostaza, E. (2000). Religion and modernity in Spain over the last forty years. In A. Pfenning and T. Bahle (Eds.), Families and Family Policies in Europe, Peter Lang, Frankfurt, pp. 162-178.

Festy P. (1980), On the New Context of Marriage in Western Europe. „Population and Development Review", 6(2), p. 311-315, follow: T. Nazio, Cohabitation, Family and Society, Routledge, New York 2008, p. 1.

Flaquer, L. (2000). Is there a Southern European model of family policy?. In A. Pfenning and T. Bahle (Eds.), Families and Family Policies in Europe, Peter Lang, Frankfurt, pp. 15-33. Haub C. (2013), Rising Trend of Births Outside Marriage, "Population Reference Bureau" - http://www.prb.org/Publications/Articles/2013/nonmarital-births.aspx - 28.07.2015.

Juszczyk-Frelkiewicz K. (2014). Kohabitacja w Polsce i na Słowacji. Studium socjologiiczne w środowiskach studenckich, Wydawnictwo Uniwersytetu Śląskiego, Katowice. 
Kiernan K. E. (2001). The rise of cohabitation and childbearing outside marriage in Europe. „International Journal of Law, Policy and the Family”, 15(1), pp. 1-21.

Kiernan K. E. (2000), European perspectives on family formation. In L. Waite et al. (Eds.), Ties that bind. Perspectives on Marriage and Cohabitation, New York, pp. 40-58.

Kwak A. (2005), Rodzina $w$ dobie przemian. Małżeństwo i kohabitacja, Warszawa, Wydawnictwo Akademickie "Żak", 2005;

Mills M., Rindfuss R. R., McDonald P. (2011), 'Why do people postpone parenthood? Reasons and social policy incentives', Egbert te Velde.

Nazio T. (2008), Cohabitation, Family and Society, Routledge, New York, p. 1.

Slany K. (2006), Alternatywne formy życia małżeńsko-rodzinnego w ponowoczesnym świecie, Kraków.

The report of the results. The National Census of Population and Housing 2011, Warsaw 2012, pp. 56-57.

\section{Web pages}

http://ec.europa.eu/eurostat - 27.07.2015.

http://ec.europa.eu/eurostat/statistics-explained/index.php/Marriage_and_divorce_statistics - 27.07.2015 year.

http://humupd.oxfordjournals.org/content/early/2011/06/06/humupd.dmr026.full.

OECD, Marriage and divorce rates, 2014, p. 6 -http://www.oecd.org/els/family/SF3_1_ Marriage_and_divorce_rate_Jan2014.pdf - 28.07.2015.

Eurostat - http://ec.europa.eu/eurostat/statistics-explained/index.php/Fertility_statistics -28.08 .2015 .

http://ec.europa.eu/eurostat/statistics-explained/index.php/File:Live_births_outside_marriage,_selected_years,_1960\%E2\%80\%932013_(share_of_total_live_births,_\%25)_ YB15.png - 27.07.2015.

Eurostat (2015), Marriages and divorces Database. Available at: http://ec.europa.eu/ eurostat/web/population-demography-migration-projections/marriages-and-divorces-data/database. [downloaded 01.08.2015]

Instituto Nacional de Estadística (INE) (1999), Encuesta de fecundidad 1999. Available at: http://www.ine.es/jaxi/menu.do?type=pcaxis\&path=\%2Ft20\%2Fp317\&file=inebase\&L $=0$ [downloaded 01.08.2015]

Instituto Nacional de Estadística (INE) (2015), Estadística de Matrimonios. Available at: http://www.ine.es/jaxi/menu.do?type=pcaxis\&path=\%2Ft20\%2Fe302\&file=inebase\&L= [downloaded 01.08.2015]

Instituto Nacional de Estadística (INE) (2014), Estadística de Nulidades, Separaciones y Divorcios. Año 2013. Nota de prensa, available at: http://www.ine.es/prensa/np867.pdf [downloaded 1.08.2015]) 